\title{
Numerical study of natural convection in an inclined enclosure: application to flat plate solar collectors
}

\author{
Charaf-Eddine Bensaci ${ }^{1}$, Adnane Labed ${ }^{1}$, Miloud Zellouf ${ }^{2}$, Abdelhafid Moummi ${ }^{1}$ \\ ${ }^{1}$ Laboratoire de Génie Mécanique (LGM), Université de Biskra, B.P. 145 R.P. 07000, Biskra, \\ Algeria \\ ${ }^{2}$ Laboratoire de Génie Energétique et Matériaux (LGEM), Université de Biskra, B.P. 145 R.P. \\ 07000, Biskra, Algeria
}

Email: adnanelabed@yahoo.fr

\begin{abstract}
In this paper, we present a numerical study of natural convection in an inclined enclosure. This was achieved in order to stimulate the convective heat exchanges that occur over the absorber of solar air flat plate collector. The considered model is an inclined enclosure with adiabatic side walls and aspect ratios $1 \leq \mathrm{AR} \leq$ 12 , and which contain heated air-filled $(\operatorname{Pr}=0.71)$. The inclination angle $\Theta$ of the enclosure was varied from $00^{\circ}$ to $90^{\circ}$ with Rayleigh numbers in the range of $10^{3} \leq \mathrm{Ra} \leq 10^{6}$. The influences of $\Theta$ and $\mathrm{Ra}$ on the flow patterns are investigated. The analysis is carried out by a numerical solution of the full governing equations; the resolution of the problem is based on the finite volumes method employing a staggered grid arrangement by the iteratively SIMPLE-C algorithm. The results indicate that there was a strong effect of inclination angle on the flow mode transition.
\end{abstract}

Keywords: Natural Convection, Solar Air Flat Plate Collector, Inclined Enclosure, Flow Mode Transition, Flow Patterns.

\section{INTRODUCTION}

Natural convection in confined cavities has received relatively little attention compared to the extensive studies of the other problems, such as: forced convection. This is not because of the greater importance of the latter problems, but rather due to the complexity of the former ones. External Natural convection problems have attracted more attention in recent years for its large applications, such as solar energy systems in inclined flat plate solar collectors, which makes it necessary to gain more understanding on the natural convection in the inclined cavities. Free convection in rectangular enclosures has been experimentally and numerically reviewed in the literature.

Many experimental investigations of heat transfer involving laminar natural convection and temperature distributions are investigated by Eckert and Carlson [1]. The same problem was studied analytically by Batchelor [2]. Ostrach [3] delimited various flow regimes in terms of the range of Grashof numbers and aspect ratio values. Elder's experimental work [4] on laminar natural convection in a vertical slot was perhaps one of the most comprehensive studies. The flow remained two dimensional in cavity with aspect ratio ranged from 1 to 60, Prandtl number equal to 103 and Rayleigh number up to $10^{8}$. In the same year Dropkin [5] conducted an experimental investigation of convective heat transfer in liquids confined by two parallel plates and inclined at various angles with respect to the horizontal. The experiments covered a range of Rayleigh numbers between $5 \times 10^{4}$ and $7.17 \times 10^{8}$, and Prandtl numbers between 0.02 and 11.56. Hart [6] studied experimentally the stability of flow in a differentially-heated, inclined, shallow box for water and air. After that Ozoe et al.[7] calculated the values of Nusselt number for natural convection heat transfer in an inclined square channel. Further, Ozoe et al. [8] investigated experimentally the flow and heat transfer with aspect ratio varied between 1 to 15.5 and $\mathrm{Ra}$ between $3.10^{3}$ to $10^{6}$. In most experiments large values of Prandtl number have been used. In 1976, Arnold et al.[9] carried out an experimental investigation of steady natural convection in finite rectangular regions, they studied the effect of angle of inclination on heat transfer across rectangular regions with several aspect ratios was measured for Rayleigh numbers varying between $10^{3}$ and $10^{6}$.Elsherbiny et al. [10] conducted an experimental study on six aspect ratios between 5 and 110 and Rayleigh number in the range of $10^{2}$ to $2 \times 10^{7}$. Hsieh and Wang [11] studied natural convection heat transfer and flow patterns in cavities.

A lot of numerical studies of natural convection inside enclosed cavities were also performed during the last few decades. In 1966 Wilkesand Churchill [12] studied numerically the natural convection of a fluid contained in a 
long horizontal enclosure of rectangular cross section. Thereafter, Aziz and Heliums [13] presented a finitedifference technique for the numerical solution of threedimensional natural convection in an enclosure. Ozoe et al. [7] determined numerically, the heat transfer and flow modes of natural convection in an inclined square channel. Further, Ozoe et al, [14] studied the natural convection flow patterns and average Nusselt number in a slightly inclined long box with aspect ratio of 2 and with glycerol as working fluid. Le Quéré and Alziary[15] studied numerically the effect of the thermal boundary conditions of the horizontal walls on the transition characteristics in a differentially heated vertical cavity with aspect ratio ranged from 1 to 10 . Lee and Lin [16]investigated numerically the three dimensional natural convection of air flow in an inclined cubic cavity, with the Rayleigh number varied from $10^{3}$ to $10^{7}$ and inclination angles from $0^{\circ}$ to $90^{\circ}$. The transition modes of the flow were also studied numerically by Soong et al [17]. Corcione [18] used numerical techniques considering the effect of bidirectional differential heating walls in horizontal cavities with several aspect ratios and Rayleigh numbers between $10^{3}$ and $10^{6}$. Flow mode transition and hysteresis phenomena for Rayleigh numbers greater than 3,000 were demonstrated by Wang and Hamed [19], they conducted a systematic numerical study of Nusselt number variation with different inclination angle and Rayleigh number ranged from $10^{3}$ up to $10^{4}$ and a single aspect ratio of 4 . Further, Khezzar et al. [20], studied two-dimensional natural convection in fluid filled cavities heated from below withvaried inclination angle. Two years later, Zhang et al [21] studied numerically thermal equilibrium distribution under different parameters of boxtype substation under two kinds of environmental. This was made order to improve the operating efficiency of the heavy oil box-type substation and reduce the construction cost, through the combination of theoretical analysis and simulation calculation method.

In this study, we have used the commercial computational fluid dynamics code Fluent for the simulation and the analysis of the proposed model. This work is part of several theoretical and experimental investigations already carried out in our laboratories [22-27], in the context of the improvement of convective heat exchange and thermal performances of solar collectors.

\section{MATHEMATICAL FORMULATION NUMERICAL SOLUTION}

AND

\subsection{Governing equations}

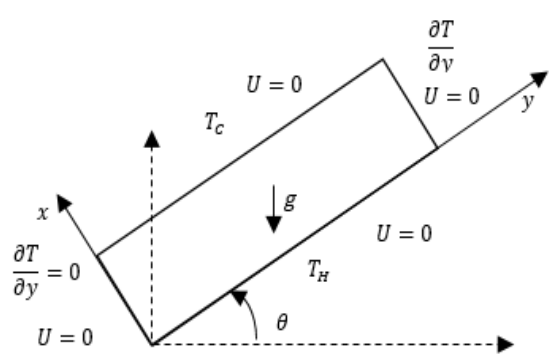

Figure 1. Schematic view of the computational domain with boundaries conditions

For the computational, Figure 1 shows the geometry of the present numerical study. The bottom and the top of the rectangular enclosure are kept at constant temperatures $\mathrm{T}_{\mathrm{H}}$ and $\mathrm{T}_{\mathrm{C}}$ respectively, and are separated by height $\mathrm{H}$. The other two facing sidewalls are adiabatic as indicated in Figure 1.

Governing equations in dimensionless form for steady two-dimensional laminar flow with constant propertiesand Boussinesq approximation are as follows.[28, 29].

\subsubsection{Non-Dimensional formulation}

Sometimes for the calculation objectives, it is useful transform the governing equations to non-dimensional equations using dimensional analysis, to extract the numbers non-dimensionalRayleigh number, Grashof and Prandtl..Etc.

Continuity Equation:

$\frac{\partial u}{\partial x}+\frac{\partial u}{\partial y}=0$

Momentum equations:

$\mathrm{x}$-direction:

$u \frac{\partial u}{\partial x}+v \frac{\partial u}{\partial y}=-\frac{\partial p}{\partial x}+\nabla^{2} u+\frac{R a}{P r} T \sin \theta$

y-direction:

$u \frac{\partial v}{\partial x}+v \frac{\partial v}{\partial y}=-\frac{\partial p}{\partial y}+\nabla^{2} v+\frac{R a}{P r} T \cos \theta$

where: $R a=\frac{\rho g \beta\left(T_{h}-T_{c}\right) H^{3}}{\alpha \mu}$,

$\operatorname{Pr}=\frac{v}{\alpha}:$ is the Prandtl number, set to 0.71 .

Energy equation:

$\frac{\partial T}{\partial t}+u \frac{\partial T}{\partial x}+v \frac{\partial T}{\partial y}=\frac{1}{P r} \nabla^{2} T$

The average Nusselt number $\mathrm{Nu}_{\mathrm{H}}$ of each horizontal boundary wall and the average Nusselt number $\mathrm{Nu}_{\mathrm{V}}$ of each vertical boundary wall are calculated:

$N u_{H}=\left.\int_{0}^{1} \frac{\partial \theta}{\partial y}\right|_{\text {wall }} d x$ and $N u_{V}=\left.\frac{1}{A R} \int_{0}^{A R} \frac{\partial \theta}{\partial x}\right|_{\text {wall }}$

In this study we interested by the heat transfer rate from the hot wall, we can use the practical formulation employed the implicit form of exchange coefficient $(\mathrm{h})$ given by:

$N u=\frac{h H}{\kappa}=\frac{\left[\frac{q}{\Delta T}\right] H}{\kappa}$

\subsection{Numerical solutions}

The system of equations (1)-(4) is solved numerically using a finite-volume method with a pressure-correction method as introduced by using the SIMPLE-C algorithm. [30].

We selected a software based on the finite volume method "FLUENT", which is the most widely used in order to provide solutions to all issues flows.

Grid independence tests were performed using four grids for the square cavity for $\mathrm{Ra}=10^{4}$ and for the four angles of inclination, $0^{\circ}, 30^{\circ}, 60^{\circ}, 90^{\circ}$. The below Table shows that 
the grid of $60 \times 60$ for $A R=1$ suffice because there is not much difference between the "Nusselt number" in the case of $58 \times 58$ and case $54 \times 54$. The same process is noted for various cavities AR.as shown in Table 1.

Table 1. Results of grid dependence test for $\mathrm{Ra}=10^{4}$ at angles of inclination $(\Theta)=00^{\circ}, 30^{\circ}, 60^{\circ}, 90^{\circ}$. Values between brackets indicate absolute percent difference to the $60 \times 60$ grid.

\begin{tabular}{lccccc}
\hline Grid & $\Theta$ & $\mathrm{Nu}$ & $\% \mathrm{Dev}$ & $\Psi_{\max } \%$ & $\mathrm{Dev}$ \\
\hline 50X50 & $00^{\circ}$ & 2.1391696 & 0.241 & 0.0095310 & 0.159 \\
50X50 & $30^{\circ}$ & 2.4177026 & 0.211 & 0.0105569 & 0.117 \\
$50 \times 50$ & $60^{\circ}$ & 2.4513596 & 0.207 & 0.0094445 & 0.068 \\
50X50 & $90^{\circ}$ & 2.2274501 & 0.225 & 0.0070324 & 0.031 \\
\hline 54X54 & $00^{\circ}$ & 2.1414865 & 0.132 & 0.0095380 & 0.085 \\
54X54 & $30^{\circ}$ & 2.4199712 & 0.117 & 0.0105626 & 0.063 \\
54X54 & $60^{\circ}$ & 2.4536031 & 0.116 & 0.0094474 & 0.038 \\
54X54 & $90^{\circ}$ & 2.2296724 & 0.126 & 0.0070333 & 0.018 \\
\hline 58X58 & $00^{\circ}$ & 2.1434588 & 0.041 & 0.0095437 & 0.026 \\
58X58 & $30^{\circ}$ & 2.4219338 & 0.036 & 0.0105673 & 0.018 \\
58X58 & $60^{\circ}$ & 2.4555669 & 0.036 & 0.0094499 & 0.011 \\
58X58 & $90^{\circ}$ & 2.2316131 & 0.039 & 0.0070342 & 0.005 \\
\hline 60X60 & $00^{\circ}$ & 2.1443383 & 0.000 & 0.0095462 & 0.000 \\
60X60 & $30^{\circ}$ & 2.4228172 & 0.000 & 0.0105693 & 0.000 \\
60X60 & $60^{\circ}$ & 2.4564575 & 0.000 & 0.0094510 & 0.000 \\
$60 \times 60$ & $90^{\circ}$ & 2.2324919 & 0.000 & 0.0070346 & 0.000 \\
\hline
\end{tabular}

\section{RESULTS AND DISCUSSION}

The present study investigates numerically the effects of cavity aspect ratio, tilt angle and the localized heat sources (presented by Rayleigh number) on the natural convection of air in inclined rectangular cavities.

The numerical simulations are performed for $\mathrm{Pr}=0.71$ Rayleigh number values in the range $10^{3} \leq \mathrm{Ra} \leq 10^{6}$, angle of inclination between $0^{\circ} \leq \Theta \leq 90^{\circ}$ and the aspect ratio of the cavity $1 \leq \mathrm{AR} \leq 12$ for $2 \mathrm{D}$ model with stationary conditions.

\subsection{Heat transfer rates}

The figures. 1-3, may provide a general idea about the variation of the heat transfer rates presented by the average Nusselt number ' $\mathrm{Nu}$ ', this was performed at various Rayleigh numbers ' $\mathrm{Ra}$ ' and inclination angles $(\mathrm{AR}=4,8,12)$. For zeroinclination, the critical Rayleigh number is about $1800(\mathrm{Nu}=$ 1.0)

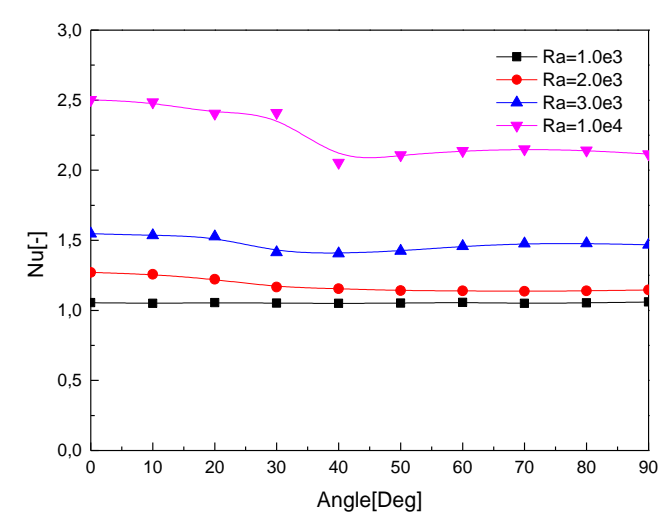

Figure 1. Average Nusselt number Versus the inclination angle $\Theta$ for different $\mathrm{Ra}$ values $(\mathrm{AR}=4)$

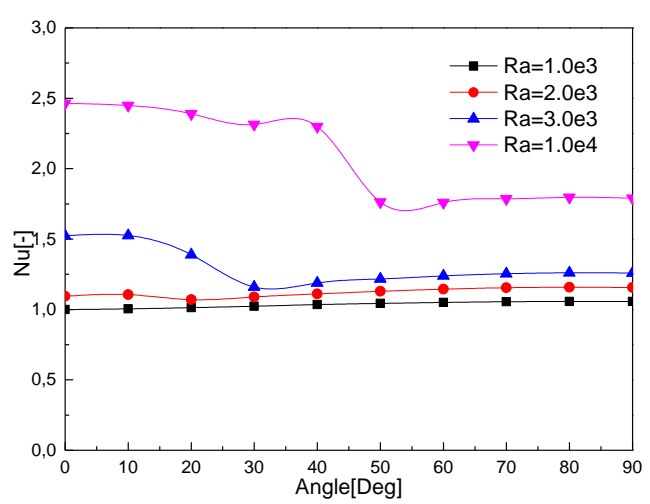

Figure 2. Average Nusselt number Versus the inclination angle $\Theta$ for different $\mathrm{Ra}$ values $(\mathrm{AR}=8)$

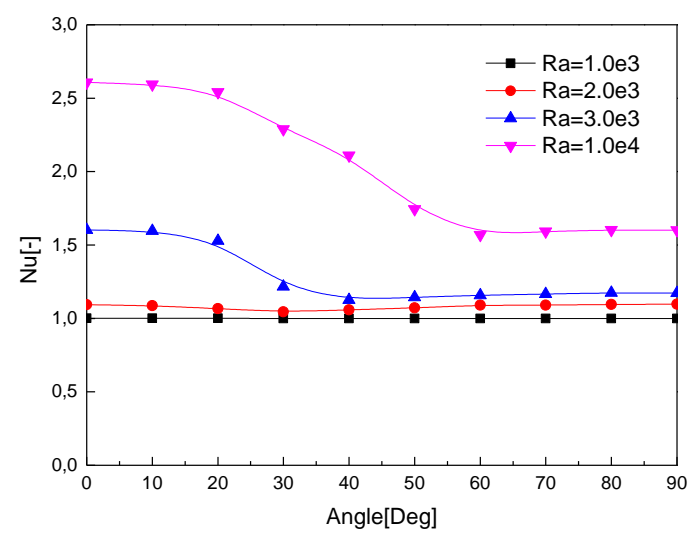

Figure 3. Average Nusselt number Versus the inclination angle $\Theta$ for different $R a$ values $(A R=12)$

For subcritical state $(\mathrm{Ra}<\mathrm{Rac})$, it is observed that there is no dominance between the two modes of heat transfer, convection and conduction.

For a higher Rayleigh number, $\mathrm{Ra}=2000$, which lies at a supercritical state, for $\Theta=0^{\circ}$ and $\mathrm{Nu}$ around 1.1, the convection contributed immediately as evidenced by the value of Nusselt number. As Ra further increased, e.g. $\mathrm{Ra}=$ 3000 or 10000 , a noticeable drop in Nusselt number appeared when increasing $\theta$. This radical change in the rate of heat transfer implied a mode-transition of the flow pattern.

We clearly distinguish on figure 4 that Nusselt number depends on Rayleigh number values, increasing Rayleigh number leads to increasing Nusselt number.

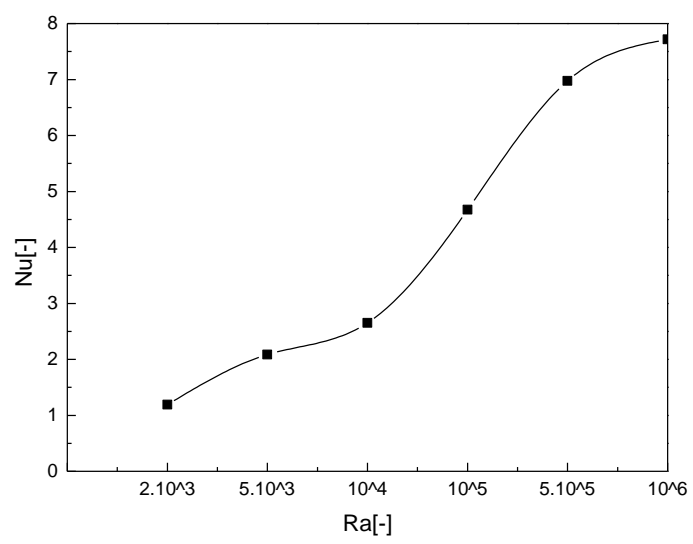

Figure 4. Average Nusselt number VersusRayleigh number $\left(\mathrm{AR}=12 / \theta=0^{\circ}\right)$ 


\subsection{Flow-mode transition}

The evolution of flow structure and temperature field illustrated by the contour lines of Stream function $\psi$ and $\theta$ for $\mathrm{Ra}$ values in the range $10^{3} \leq \mathrm{Ra} \leq 10^{4}$ and $\mathrm{AR}=12,8$ and 4 , are represented in figures. 5-13, respectively.

The effect of the inclination angle is also shown in figure 5 for $\mathrm{AR}=12$ andRa $=2.10^{3}$, it is found that the initial multi-cell pattern of 12 cell observed at $0^{\circ}$ gradually shifts to a lower number of 11 cells at an angle of $2^{\circ}$ and decreases with the increase of the inclination angle. Some cells begin to fade at $13^{\circ}$, to become six $(06)$ cells at $14^{\circ}$, they start to overlap later at the angle $20^{\circ}$ and become almost only one cell at the angle $30^{\circ}$ and completely one cell at the angle $90^{\circ}$.

The same structures are noticed in figure 6 for $\mathrm{Ra}=3.10^{3}$ and at the angle $0^{\circ}$, they become 11 cells at the angle $15^{\circ}$, and 6 cells at $24^{\circ}$, then 4 cells at $25^{\circ}$, These cells shrink to almost three (03) cells at $26^{\circ}$, and diminished to a one cell at $30^{\circ}$.

In Figure 8. The fluid in this subcritical state $\left(\mathrm{Ra}=10^{3}<\right.$ $\mathrm{Rac})$ is still considered as stationary. As the enclosure is inclined, $\theta=1^{\circ}$, the shear flow along the two longitudinal walls results a large circulation in which there are two weak sub-cells rotating in the same sense as the primary cell. This two cellular structure disappears at an inclination angle between $48^{\circ}$ and $49^{\circ}$ due to stronger upslope/downslope flows along the $\mathrm{x}$-direction. For $\theta \geq 50^{\circ}$, the flow field is onecell mode. The isotherms illustrate a gradual change from a stratification state to a skewsymmetric distortion due to the cellular motion.

Figure 9. Shows a four-cell structure at $\theta=0^{\circ}$ for a rectangular enclosure with $\mathrm{AR}=4$, the four- cell structure remained up to $\theta=21^{\circ}$, and it changed to a three-cell structure in $\theta=22^{\circ}$, in the inclination angle $\theta=38^{\circ}$ being to the threecell structure changes to a one cell.

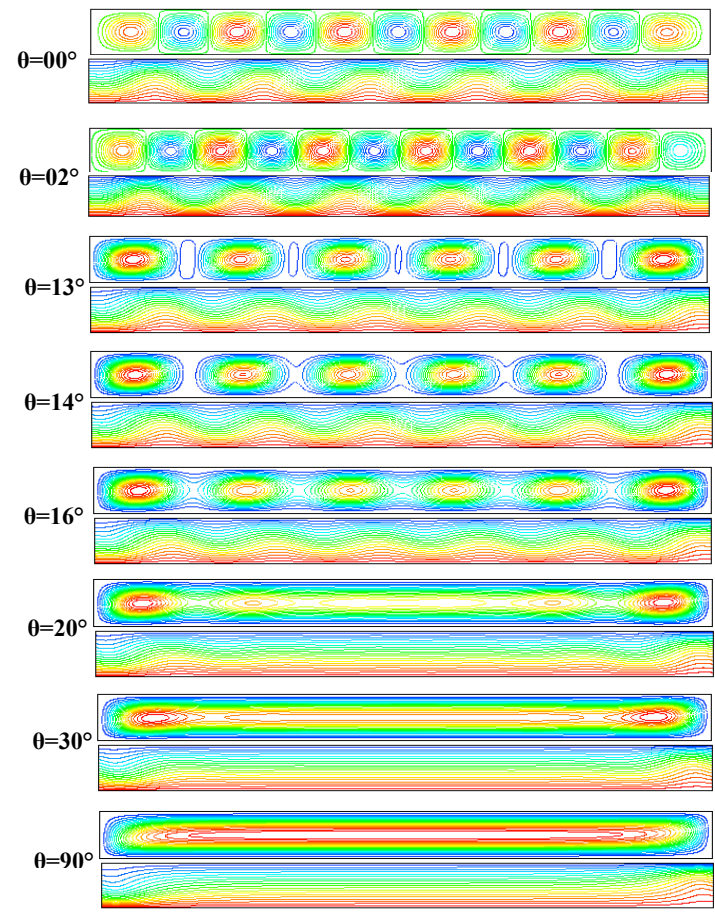

Figure 5. Stream function and Temperature contours at inclination $\theta$ for $\mathrm{AR}=12$ and $\mathrm{Ra}=2.10^{3}$

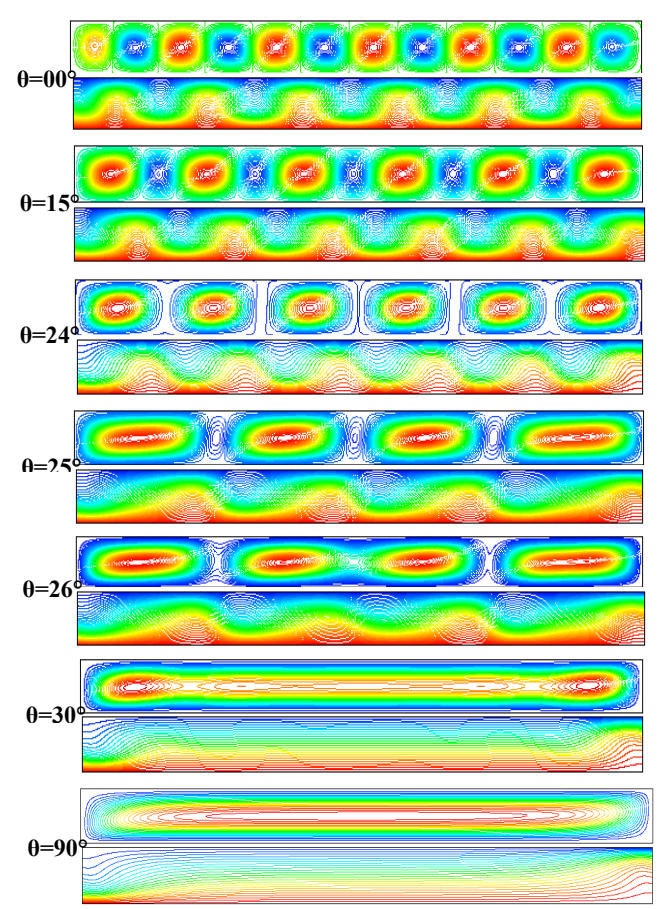

Figure 6. Stream function and Temperature contours at inclination $\theta$ for $\mathrm{AR}=12$ and $\mathrm{Ra}=3.10^{3}$

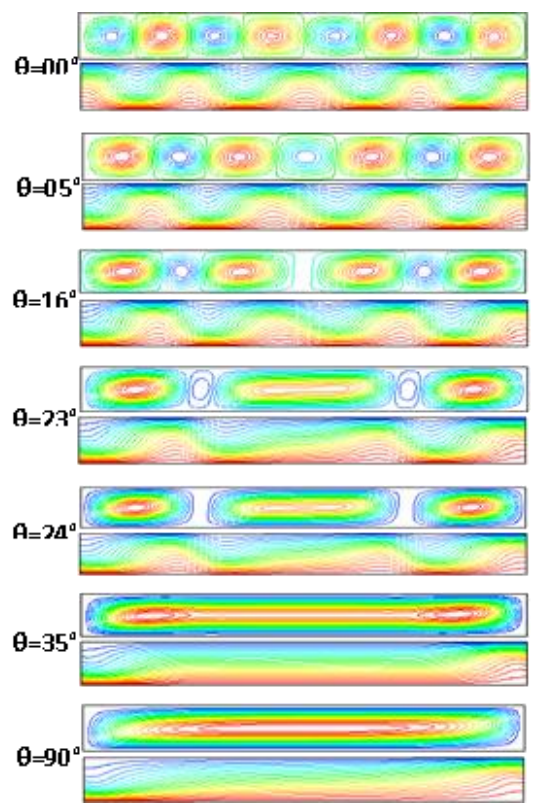

Figure 7. Stream function and Temperature contours at inclination $\theta$ for $\mathrm{AR}=8$ and $\mathrm{Ra}=3.10^{3}$

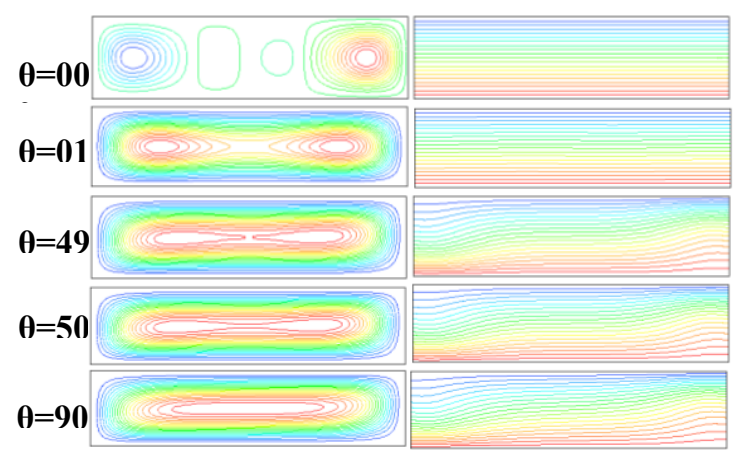

Figure 8. Stream function and Temperature contours at inclination $\theta$ for $\mathrm{AR}=4$ and $\mathrm{Ra}=10^{3}$ 


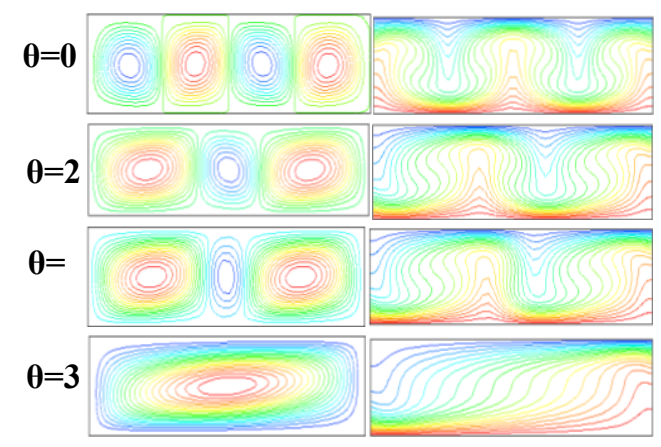

Figure 9. Stream function and Temperature contours at inclination $\theta$ for $\mathrm{AR}=4$ and $\mathrm{Ra}=10^{4}$

\section{CONCLUSIONS}

In this work we investigate the natural convection flow in rectangular cavities by using many controlled parameters such as: the aspect ratio (AR) , inclination angle $(\Theta)$ and Rayleigh number (Ra), where the Prandtl number (Pr) is fixed in all the study. We propose a phenomenological study about the influence of some parameters on the flow patterns and heat transfer rate (average Nusselt number). The analysis is carried out by a numerical solution of the full governing equations, on the basis of the finite volumes approach employing a staggered grid arrangement by the iterative SIMPLE-C algorithm. The results indicate that there is a sensible effect of the inclination angle on the flow mode transition and multiplicity of solutions at various Rayleigh numbers. The existence of such multi-steady solutions strongly depends on the value of Rayleigh number, it is also found, that the inclination angle whene the minimum heat transfer occurs, has a close relationship with the flow structure transition

\section{REFERENCES}

[1] Batchelor G.K. (1954). Heat transfer by free convection across a closed cavity between vertical boundaries at different temperatures, Q. Appl. Math, Vol. 12, pp. 209-233. DOI: 10.1090/qam/64563

[2] Eckert R.G., Carlson W.O. (1961). Natural convection in an air layer enclosed between two vertical plates at different temperatures, Int. J. Heat Mass Trans, Vol. 2, pp. 106-29.

[3] Ostrach S. (1972). Natural convection in enclosures, Advances in Heat Transfer. Ed. J. P.Hartnett and T. F. Irvine, Vol. 8, pp. 161-227.

[4] Elder J.W. (1965). Laminar free convection in a vertical slot, Journal of Fluid Mechanics, pp. 77. DOI: 10.1017/S0022112065001246

[5] Dropkin D.S. (1965). Heat transfer by natural convection in liquids confined by two parallel plates which are inclined at various angles with respect to the horizontal, J. Heat Transfer, pp. 17-84.

[6] Hart E.J. (1971). Stability of the flow in differentially heated inclined box, Journal of Fluid Mechanics, Vol. 47, pp. 547-576.

[7] Hiroyuki O., Hayatoshi S., Churchill S.W. (1974). Natural convection in an inclined square channel, International Journal of Heat and Mass Transfer, Vol.
17, pp. 401-406. DOI: $\underline{10.1016 / 0017-9310(74) 90011-}$ $\underline{8}$

[8] Hiroyuki O., Hayatoshi S., Churchill S.W. (1975). Natural convection in an inclined rectangular channel at various aspect ratios and angles - experimental measurements, International Journal of Heat and Mass Transfer, Vol. 18, pp. 1420-1425.

[9] Arnold J.N., Catton I., Edwards D.K. (1976). Experimental investigation of natural convection in inclined rectangular regions of differing aspect ratios, Journal of Heat Transfer, Vol. 98, pp. 67-71. DOI: $\underline{10.1115 / 1.3450472}$

[10] Elsherbiny S.M., Raithby G.D., Hollands K.G.T (1982). Heat transfer by natural convection across vertical and incline air layers, ASME Journal of Heat Transfer, Vol. 104, pp. 96-102. DOI: $\underline{10.1115 / 1.3245075}$

[11] Hsieh S.S., Wang C.Y. (1994). Experimental study of three-dimensional natural convection in enclosure with different working fluids, International Journal of Heat and Mass Transfer, Vol. 37, pp. 2687. DOI: 10.1016/0017-9310(94)90385-9

[12] Wilkes J.O., Churchill S.W. (1966). The finite difference computation of natural convection in a rectangular enclosure, A.1.Ch.E. Journal, Vol. 12, pp. 161-166.

[13] Aziz K., Heliums J.D. (1967). Numerical solution of the three-dimensional equations of motion for laminar natural convection, Physics of Fluids, Vol. 10, pp. 314. DOI: 10.1063/1.1762111

[14] Ozoe H., Sayama H., Churchill S.W. (1977). Natural convection patterns in a long inclined rectangular box heated from below, Part 1: three-Directional photography, International Journal of Heat and Mass Transfer, Vol. 20, pp. 123-129. DOI: 10.1016/00179310(77)90004-7

[15] QuéréL., Alziary T. (1986). Transition to unsteady natural convection of air in vertical differentially heated cavity: influence of thermal boundary conditions on the horizontal walls, Proceedings of the Eighth International Heat Transfer Conference, San Fransisco, USA.

[16] Lee T.L., Lin T.F. (1995). Three-Dimensional natural convection of air in an inclined cubic cavity, Numerical Heat Transfer, Part A: Applications, Vol. 27, pp. 681-703.

[17] Soong C.Y., Tzeng P.Y., Chiang D.C., Sheu T.S. (1996). Numerical study on mode-transition of natural convection in differentially heated inclined enclosures, International Journal of Heat and Mass Transfer, Vol. 39, pp. 2869-2882. DOI: $\underline{10.1016 / 0017-}$ 9310(95)00378-9

[18] Corcione M. (2003). Effects of the thermal boundary conditions at the side walls upon natural convection in rectangular enclosures heated from below and cooled from above, Int J Thermal Sciences, Vol. 42, pp. 199 208. DOI: 10.1016/S1290-0729(02)00019-4

[19] Wang H., Hamed M.S. (2006). Flow mode-transition of natural convection in inclined rectangular enclosures subjected to bidirectional temperature gradients, International Journal of Thermal Sciences, Vol. 45, pp. 782-795. DOI: 10.1016/j.ijthermalsci.2005.07.008

[20] Khezzar L., Siginer D., Vinogradov I. (2012). Natural convection in inclined two dimensional rectangular 
cavities, Journal of Heat and Mass Transfer, Vol. 48, pp. 227-239.

[21] Zhang J.X., Wang X.R., Bo L., Liu C.P. (2015). Thermal equilibrium analysis of heavy oil box-type substation, Mathematical Modelling of Engineering Problems, Vol. 2, No. 2, pp. 15-18. DOI: 10.18280/mmep.020204

[22] Rouag A., Benchabane A., Labed A., Boultif N. (2016). Thermal design of air cooled condenser of a solar adsorption refrigerator, Journal of Applied Engineering Science \& Technology, Vol. 2, No. 1, pp. 23-29.

[23] Labed A., Rouag A., Benchabane A., Moummi N., Zerouali M. (2015). Applicability of solar desiccant cooling systems in Algerian Sahara: experimental investigation of flat plate collectors, Journal of Applied Engineering Science \& Technology, Vol. 1, No. 2, pp. 61-69.

[24] Labed A., Moummi N., Benchabane A. (2012). Experimental investigation of various designs of solar flat plate collectors: application for the drying of green chili, Journal of Renewable and Sustainable Energy, Vol. 4, No. 4, pp. 043116. DOI: org/10.1063/1.4742337

[25] Rouag A., Benchabane A., Labed A., Belhadj K., Boultif N. (2016). Applicability of a solar adsorption cooling machine in semiarid regions: proposal of supplementary cooler using earth-water heat exchanger, International Journal of Heat and Technology, Vol. 34, No. 2, pp. 281-286. DOI: 10.18280/ijht.340218

[26] Labed A., Moummi N., Benchabane A., Zellouf M. (2015). Experimental analysis of heat transfer in the flow channel duct of solar air heaters (SAHs), International Journal of Heat And Technology, Vol. 33, No. 3, pp. 97-102. DOI: 10.18280/ijht.330314

[27] Labed A., Moummi N., Aoues K., Benchabane A. (2016). Solar drying of henna (Lawsonia inermis) using different models of solar flat plate collectors: an experimental investigation in the region of Biskra (Algeria), Journal of Cleaner Production, Vol. 112, pp. 2545-2552. DOI: 10.1016/j.jclepro.2015.10.058

[28] Chandrasekhar S. (1961). Hydrodynamic, Hydromagnetic Stabilit, Oxford University Press, pp. 654.
[29] Lappa M. (2010). Thermal Convection: Patterns, Evolution and Stability, John Wiley \& Sons, Italy.

[30] Patankar S.V. (1980). Numerical Heat Transfer and Fluid Flow. Series in Computational Methods in Mechanics and Thermal Sciences, Hemisphere, Washington, pp. 380.

\section{NOMENCLATURE}

$\begin{array}{ll}\mathrm{AR} & \text { aspect ratio } \\ \mathrm{H} & \text { height of the side wall, } \mathrm{m} \\ \mathrm{L} & \text { length of the side wall, } \mathrm{m} \\ \mathrm{q} & \text { Heat flux, } \mathrm{Wm}^{-2} \\ \mathrm{~h} & \text { Heat transfer coefficient, } \mathrm{Wm}^{-2} \mathrm{~K}^{-1} \\ \mathrm{Nu} & \text { mean Nusselt number } \\ \mathrm{Ra} & \text { Rayleigh number } \\ \mathrm{Pa} & \text { Prandtl number } \\ \mathrm{g} & \text { gravitational acceleration, } \mathrm{ms}^{-2} \\ \mathrm{~T} & \text { temperature, } \mathrm{K} \\ \mathrm{P} & \text { pressure, } \mathrm{Nm}^{-2} \\ \mathrm{U} & \text { velocity, } \mathrm{ms}^{-1} \\ \mathrm{t} & \text { time, } \mathrm{s} \\ \mathrm{x}, \mathrm{y} & \text { coordinates }\end{array}$

\section{Greek symbols}

$\begin{array}{ll}\alpha & \text { thermal diffusivity, } \mathrm{m}^{2} \mathrm{~s}^{-1} \\ \beta & \text { thermal expansion, } \mathrm{K}^{-1} \\ \mathrm{~K} & \text { Thermal conductivity, } \mathrm{Wm}^{-1} \mathrm{~K}^{-1} \\ \mu & \text { dynamic viscosity, } \mathrm{kg} \mathrm{m}^{-1} \mathrm{~s}^{-1} \\ \nu & \text { kinematic viscosity, } \mathrm{m}^{2} \mathrm{~s}^{-1} \\ \rho & \text { fluid density, } \mathrm{kg} \mathrm{m} \mathrm{m}^{-3} \\ \Psi_{\max } & \text { dimensionless stream function } \\ \Theta & \text { inclination angle, deg }\end{array}$

\section{Subscripts}

cold wall

hot wall

horizontal wall

vertical wall 